\section{Adverse events involving levothyroxine in patients treated at the toxicological assistance center of São Paulo}

\author{
Marina Romera Cavallari ${ }^{1}$, Anthony Wong ${ }^{2}$, Leandro Luongo Matos ${ }^{3}$
}

\begin{abstract}
Introduction: Thyroxine is prescribed for patients with thyroid hormone deficiency in the event of hypothyroidism or thyroidectomy. Objective: The Toxicological Assistance Center of Sao Paulo (CEATOX-SP) aims to provide specific information to the general public and health professionals in the event of poisoning, exposure to toxic substances, accidents with venomous animals, and adverse drug reactions, assisting with diagnosis and treatment. This study assesses the epidemiology of adverse events involving levothyroxine reported at the CEATOX-SP. Materials and Methods: This is a crosssectional, retrospective study involving cases of therapeutic error, adverse reaction, individual accident with medication, and substance abuse involving levothyroxine, between 2013 and 2015. Results: During the study period, a total of 39,501 patients were treated at the CEATOX-SP, with 1\% (396) of the cases involved the use of levothyroxine, and most occurrences (77.8\%) were reported in the state of Sao Paulo. All occurrences were domestic; however, the CEATOX-SP was most contacted by physicians, after assistance at health services. Mean age of the patients was $24.4 \pm 26.2$ years, and $68.9 \%$ of them were female. The most common circumstance was "individual accident" (47.5\%), the most prevalent type of exposure was "acute only" (56.3\%), and the most predominant type of occurrence was "exposure" (73.5\%). The main reason for seeking the service were accidents involving children, who found tablets in the house and ingested them. Conclusion: Accident prevention campaigns targeting children and medicines, and awareness of health professionals about the importance of medical prescription can reduce the number of adverse events involving levothyroxine.
\end{abstract}

Keywords: thyroxine; drug effects; prescription drug misuse; pharmacovigilance.

\section{Introduction}

Thyroxine is a hormone normally synthesized by the thyroid gland. It is prescribed as medicine for patients with thyroid hormone deficiency in the event of hypothyroidism or thyroidectomy".

There are few studies addressing adverse events of levothyroxine in humans. Of the twelve articles found in the literature, five address the clinical manifestations and management of levothyroxine intoxication ${ }^{2-6}$, three are case reports of suicide attempts using this drug $7-9$, three are case reports of levothyroxine intake by children ${ }^{10-12}$, and there is only one report on the use of this medicine for the purpose of weight loss, which eventually resulted in death ${ }^{13}$. 
Epidemiological study of the adverse events involving levothyroxine is essential for understanding the scenario of exposure to this drug. Knowledge about the risks and main causes of intoxication and inappropriate exposure to levothyroxine will enable the outline of strategies aimed at future prevention of such events.

This study aimed to assess the epidemiology of cases of therapeutic error, adverse reaction, individual accident with medication, and substance abuse involving levothyroxine reported to the Toxicological Assistance Center of Sao Paulo (CEATOX-SP) ${ }^{14}$.

\section{Material and methods}

This cross-sectional, retrospective study was approved by the Research Ethics Committee under protocol no. 58098116.9.0000.0082.

Data were collected from the Toxicological Event Notification Forms of the CEATOX-SP, which included the use of drugs with levothyroxine as active principle, between July 2013 (when the digital data classification form came into use) and December 2015.

Inclusion criteria comprised treatment involving humans with a duly completed record in the CEATOX-SP database on the following circumstances: therapeutic error, adverse reaction, or individual accident with levothyroxine.

\section{Toxicological Events Notification Form}

The Toxicological Events Notification Form was developed from the integration of the general data structure of notifications common to the National Notifiable Diseases Information System ${ }^{15}$ (SINAN) and specific to the National Poisoning Information System (SINITOX). This procedure aimed to integrate the CEATOX units and implement notification of cases of toxicological events at the various levels of the Public Health System of Sao Paulo State (SUS) ${ }^{16}$.

To complete this form, patients were required to inform the toxicological event and its circumstance. Events include intoxication, exposure, adverse reaction, differential diagnosis, and withdrawal syndrome; whereas the following situations are considered as circumstances of the toxicological event in question: individual accident, collective accident, environmental accident, occupational accident, therapeutic use, inadequate medical prescription, therapeutic error, self-medication, abstinence, substance abuse, suicide attempt, attempted abortion, and violence or homicide.

The aforementioned events are defined according to the Health Surveillance Center as follows ${ }^{17}$ :

- Intoxication: cases in which after exposure to a particular type of chemical product and/or substance, biochemical, functional changes and/or clinical signs compatible with poisoning condition are observed;

- Exposure: cases exposed to some type of chemical product and/or substance, but no biochemical, functional changes and/or signs and symptoms compatible with poisoning condition are observed;

- Adverse reaction to medicine: cases in which the patient shows unexpected and undesirable symptomatology resulting from the use of a prophylactic, 
curative, palliative or diagnostic purpose at a proven therapeutic dose. This group includes from discrete manifestations (e.g., malaise, gastric discomfort, etc.) to conditions such as severe idiosyncratic reactions and anaphylaxis;

- Differential diagnosis: cases in which it is necessary to exclude the possibility of intoxication as responsible for the symptomatology presented by the patient;

- Withdrawal syndrome: cases in which the patient shows reaction due to suspended use of the drug or chemical that causes addiction.

The following circumstances were assessed in this study:

- Therapeutic error: cases in which the patient, despite having a medical prescription, is medicated (including by a health professional) or uses the medication in a manner different from the prescribed;

- Substance abuse: cases arising from the intentional use of licit drugs (alcohol, nicotine, medicine, etc.) and/or illicit drugs (prohibited and proscribed in the Country) or other toxic agent, for the purpose of obtaining a stimulatory and/or hallucinogenic effect, without suicidal intention;

- Suicide attempt: cases of poisoning/exposure through intentional use of any chemical product and/or substance with the intention of committing suicide;

- Accident with medicine: cases of unintentional intoxication/exposure with any chemical product and/or substance, in a single victim that do not fit into the other items.

The types of exposure were as follows:

- Acute only: a single exposure;

- Acute repetitive: more than one exposure within 15 days;

- Acute over chronic: cases of acute exposure in patients chronically exposed to the same chemical product and/or substance;

- Chronic: exposure for over 15 days.

\section{Statistical analysis}

Qualitative variables were described in absolute frequencies, whereas the relative and quantitative variables were analyzed by mean and standard deviation. Data were processed using Microsoft Excel ${ }^{\circledR}$ (Microsoft Corporation ${ }^{\circledR}$, Redmond, Washington, USA).

Qualitative evaluation was performed through analysis of repetitions according to the methodology proposed by Minayo ${ }^{18}$. This analysis was conducted with the reports of the patients who sought the CEATOX-SP, which is duly registered and aimed at critically reviewing the theories on the theme in a specific and contextualized way.

\section{Results}

During the study period, 39,501 patients were treated at the CEATOX-SP, with $1 \%$ (396) of the cases involving the use of levothyroxine. All occurrences involving levothyroxine were domestic, and most occurrences $(77.8 \%)$ were 
reported in the state of Sao Paulo, followed by Rio de Janeiro state $(7.8 \%)$. Mean age of the patients was $24.4 \pm 26.2$ years, and $68.9 \%$ of them were female.

"Individual accident" was the most common circumstance with $47.5 \%$ of the cases, followed by therapeutic error with $34.6 \%$. Table 1 shows the cases of notification of levothyroxine subdivided according to the circumstance of exposure to medicine that led the notifier to contact the CEATOX-SP.

Table 2 presents the cases involving levothyroxine subdivided according to the type of exposure. The most prevalent type of exposure in this study was "acute only" with $56.3 \%$ of the cases, that is, in most of the cases reported to CEATOX-SP, the patient did not make use of levothyroxine prior to exposure. "Acute over chronic" was the second most prevalent type of exposure with $26.3 \%$ of the cases.

The most common type of occurrence in the total number of cases studied was "exposure", with $73.5 \%$, meaning that most patients who reported to CEATOX-SP showed no symptoms compatible with intoxication or adverse reaction to levothyroxine. In contrast, cases of "intoxication" (11.4\%) and "adverse reaction" (8.1\%) presented symptoms associated with the use of

Table 1. Circumstance of treatment involving levothyroxine.

\begin{tabular}{lcc}
\multicolumn{1}{c}{ Circumstance } & N & $\%$ \\
\hline INDIVIDUAL ACCIDENT & 188 & $47.5 \%$ \\
\hline THERAPEUTIC ERROR & 137 & $34.6 \%$ \\
\hline THERAPEUTIC USE & 35 & $8.8 \%$ \\
\hline SUICIDE ATTEMPT & 11 & $2.8 \%$ \\
\hline INFORMATION & 9 & $2.3 \%$ \\
\hline COLLECTIVE ACCIDENT & 6 & $1.5 \%$ \\
\hline PRESCRIPTION DRUG MISUSE & 6 & $1.5 \%$ \\
\hline SELF-MEDICATION & 2 & $0.5 \%$ \\
\hline ATTEMPTED ABORTION & 1 & $0.3 \%$ \\
\hline UNKNOWN & 1 & $0.3 \%$ \\
\hline
\end{tabular}

Table 2. Type of exposure in treatment involving levothyroxine.

\begin{tabular}{|c|c|c|}
\hline Type of Exposition & $\mathbf{N}$ & $\%$ \\
\hline ACUTE ONLY & 223 & $56.3 \%$ \\
\hline ACUTE OVER CHRONIC & 104 & $26.3 \%$ \\
\hline INFORMATION & 47 & $11.9 \%$ \\
\hline ACUTE REPETITIVE & 15 & $3.8 \%$ \\
\hline CHRONIC & 4 & $1.0 \%$ \\
\hline UNKNOWN & 3 & $0.8 \%$ \\
\hline
\end{tabular}


this drug. Table 3 summarizes the cases involving levothyroxine subdivided according to the types of occurrence. Table 4 describes all signs and symptoms reported by patients who took levothyroxine.

Table 5 shows the cases involving levothyroxine subdivided according to the notifier. It can be observed that, although all of the cases occurred in the patients' homes, physicians were responsible for most of the contacts with CEATOX-SP. However, in the total of the cases studied, patients are the main notifiers with $39.9 \%$, followed by physicians with $31.6 \%$.

Table 3. Type of occurrence in treatment involving levothyroxine.

\begin{tabular}{lcc}
\hline \multicolumn{1}{c}{ Type of Occurrence } & N & $\%$ \\
\hline EXPOSURE & 291 & $73.5 \%$ \\
\hline INTOXICATION & 41 & $11.4 \%$ \\
\hline ADVERSE REACTION & 32 & $8.1 \%$ \\
\hline DIFFERENTIAL DIAGNOSIS & 15 & $3.8 \%$ \\
\hline INFORMATION & 13 & $3.3 \%$ \\
\hline
\end{tabular}

Table 4. Signs and symptoms reported by patients taking levothyroxine.

\begin{tabular}{llll}
\hline \multicolumn{1}{c}{ Symptoms } & $\mathbf{N}(\%)$ & & Symptoms \\
\hline MUSCLE SPASMS & $1(0.6 \%)$ & INSOMNIA* & $4(2.2 \%)$ \\
\hline AGITATION & $4(2.2 \%)$ & RENAL FAILURE & $1(0.6 \%)$ \\
\hline AMENORRHEA* & $1(0.6 \%)$ & RESPIRATORY FAILURE & $1(0.6 \%)$ \\
\hline ANOREXIA* & $3(1.7 \%)$ & IRRITABILITY & $6(3.3 \%)$ \\
\hline ANXIETY* & $1(0.6 \%)$ & EYE IRRITATION & $1(0.6 \%)$ \\
\hline APATHY & $1(0.6 \%)$ & EXTRAPYRAMIDAL SYMPTOMS & $1(0.6 \%)$ \\
\hline ARRHYTHMIA & $4(2.2 \%)$ & MALAISE & $6(3.3 \%)$ \\
\hline ASTHENIA* & $8(4.4 \%)$ & RIGHT EYE STAIN & $1(0.6 \%)$ \\
\hline BRADYCARDIA & $1(0.6 \%)$ & NAUSEA* & $4(2.2 \%)$ \\
\hline CRAMP* & $2(1.1 \%)$ & NERVOUSNESS & $2(1.1 \%)$ \\
\hline HEADACHE* & $8(4.4 \%)$ & CONSTIPATION & $1(0.6 \%)$ \\
\hline RENAL COLIC & $1(0.6 \%)$ & PALLOR & $2(1.1 \%)$ \\
\hline MENTAL CONFUSION & $5(2.8 \%)$ & PALPITATION* & $3(1.7 \%)$ \\
\hline DIARRHEA* & $7(3.9 \%)$ & PARESTHESIA & $3(1.7 \%)$ \\
\hline LOW EJECTION FRACTION & $1(0.6 \%)$ & WEIGHT LOSS* & $1(0.6 \%)$ \\
\hline DYSPEPSIA & $2(1.1 \%)$ & POLYDIPSIA & $1(0.6 \%)$ \\
\hline DYSPNEA & $4(2.2 \%)$ & PROSTRATION & $1(0.6 \%)$ \\
\hline
\end{tabular}

Captions: * ${ }^{*}$ constant symptoms described in the medicine package insert ${ }^{19}$. 
Table 4. Continued...

\begin{tabular}{|c|c|c|c|}
\hline Symptoms & $\mathbf{N}(\%)$ & Symptoms & $\mathbf{N}(\%)$ \\
\hline ABDOMINAL PAIN* & $6(3.3 \%)$ & PRURITUS & $2(1.1 \%)$ \\
\hline LIMB PAIN & $1(0.6 \%)$ & SKIN RASH* & $1(0.6 \%)$ \\
\hline BACKACHE & $2(1.1 \%)$ & LOW LEVEL OF CONSCIOUSNESS & $1(0.6 \%)$ \\
\hline NAPE PAIN & $1(0.6 \%)$ & RECTAL BLEEDING & $1(0.6 \%)$ \\
\hline UNSPECIFIED PAIN & $1(0.6 \%)$ & HYPOSALIVATION & $1(0.6 \%)$ \\
\hline CHEST DISCOMFORT* & $2(1.1 \%)$ & DROWSINESS & $9(5.0 \%)$ \\
\hline EDEMA & $1(0.6 \%)$ & SWEATING* & $3(1.7 \%)$ \\
\hline EXANTHEMA & $1(0.6 \%)$ & TACHYCARDIA* & $8(4.4 \%)$ \\
\hline FEVER* & $3(1.7 \%)$ & TACHYPNEA & $1(0.6 \%)$ \\
\hline YELLOW STOOLS & $1(0.6 \%)$ & DIZZINESS & $12(6.6 \%)$ \\
\hline HOT FLUSHES* & $1(0.6 \%)$ & $\mathrm{COUGH}$ & $2(1.1 \%)$ \\
\hline HYPERACTIVITY & $1(0.6 \%)$ & TREMORS* & $2(1.1 \%)$ \\
\hline HYPEREMIA & $3(1.7 \%)$ & VERTIGO & $1(0.6 \%)$ \\
\hline HYPERTENSION & $4(2.2 \%)$ & VOMITING* & $10(5.5 \%)$ \\
\hline HYPOTENSION & $4(2.2 \%)$ & XEROSTOMIA & $2(1.1 \%)$ \\
\hline
\end{tabular}

Captions: *constant symptoms described in the medicine package insert ${ }^{19}$.

Table 5. Notifiers of cases involving levothyroxine.

\begin{tabular}{lccc} 
& Type of Notifier & $\mathbf{N}$ & \% \\
\hline PATIENT & 158 & $39.9 \%$ \\
\hline PHYSICIAN & 125 & $31.6 \%$ \\
\hline RELATIVE & 104 & $26.3 \%$ \\
\hline NURSE & 8 & $2.0 \%$ \\
\hline PHARMACIST & 1 & $0.3 \%$ \\
\hline
\end{tabular}

\section{Qualitative analysis}

In this study, the main reason for seeking the toxicological service was "individual accident" of the "acute" type, usually involving children who found tablets in the house and ingested them. "Therapeutic error", usually of "acute over chronic" type, was second, comprising mostly cases in which the patient, in spite of having a medical prescription, was medicated (including by a health professional) or used the medication in a manner different from the prescribed.

"Acute over chronic" ingestions occurred mostly in patients who mistook levothyroxine for some other daily use medicine. Another common event was the double administration of the medicine, either a child medicated by 
the mother and then by the father, or adults who forgot they had already taken the medicine and ingested it again. However, there were also cases of patients who, because of the need to take more than one tablet with different dosages of levothyroxine to complete the daily dose, ended up ingesting erroneous amounts of each. Exposures of the "chronic" type mostly reported adverse effects on medication.

It is noteworthy that, although the number of reports of prescription drug misuse and self-medication were not significant, the majority of patients were symptomatic of levothyroxine intoxication. The cases included from patients who increased the dose on their own to those who had no indication of use, but took the medicine with the purpose of losing weight.

\section{Discussion}

The present study describes for the first time events involving levothyroxine regarding therapeutic error, adverse reaction, individual accident with the medicine, and substance abuse in Brazil. The cases represent a small universe of the treatments at the CEATOX-SP, the largest service in the country, but they are very significant for the professionals who manage this medicine on a daily basis.

In the reviewed literature, $38.5 \%$ of the documented cases are "individual accidents", $30.8 \%$ are "suicide attempts", $15.4 \%$ refer to "prescription drug misuse" for weight loss, and $7.7 \%$ are classified as "therapeutic error". There is predominance of the female gender (92.3\%). As for type of exposure, $53.8 \%$ of the cases are "acute only", 23.1\% refer to "acute over chronic", $5.4 \%$ are "acute repetitive", and $7.7 \%$ are classified as "chronic". Of the cases reported in the literature, $76.9 \%$ were "intoxication" and only $23.1 \%$ were "exposure" "6,7,12. These results somewhat differ from those obtained in this study, which was expected because most of the studies were case reports, and there are no epidemiological studies in the literature.

$\mathrm{Papi}^{3}$, in a review of causes and treatment of thyrotoxicosis, stated that the most common cause of thyrotoxicosis is the use of excessive doses of levothyroxine for the treatment of hypothyroidism, nontoxic goiter, or thyroid carcinoma (exogenous thyrotoxicosis).

De Luis et al. ${ }^{4}$ conducted a review on levothyroxine intoxication in which they suggested that the T3 and T4 levels and the elapsed time of ingestion are not associated with severity of intoxication, but monitoring of the serum levels of these hormones is necessary for the therapeutic and prognostic approach.

The finding that physicians are the main notifiers showed that adverse events with levothyroxine often take the patient to the hospital, and that doctors themselves still have doubts on how to manage and treat such events. With $73.5 \%$ of the occurrences referring to "exposure" and only $11.4 \%$ corresponding to "intoxication", it can be stated that the majority of patients who were exposed to levothyroxine and contacted the CEATOX-SP did not present symptoms of this drug. Only $45.3 \%$ of the symptoms reported were described in the medicine package insert. However, the symptoms were 
analyzed, including cases not classified as "intoxication", thus presenting a symptom not consistent with the use of levothyroxine.

Domestic accident prevention strategies involving children and medication should be improved, emphasizing that medicines should be kept in safe and out of reach places. It is also important that awareness-raising campaigns are developed for health professionals, so that they understand the importance of explaining prescriptions to patients.

Another possible strategy, aimed at patients/caregivers, would be to separate the medicines according to days and prescribed dosages in order to avoid forgetting or double administration.

\section{References}

1. Brasil. Ministério da Saúde. Nota Técnica N³32/2013. Brasília: Consultoria Jurídica/ Advocacia Geral da União; 2013.

2. Kreisner E, Lutzky M, Gross JL. Charcoal hemoperfusion in the treatment of levothyroxine intoxication. Thyroid. 2010;20(2):209-12. http://dx.doi.org/10.1089/ thy.2009.0054. PMid:20151829.

3. Papi G. Current issues in the treatment of thyrotoxicosis. Recenti Prog Med. 2005;96(11):560-5.

4. Luis DA, Abad L, Aller R, González-Sagrado M, Dueñas A. Levothyroxine poisoning: clinical manifestations and therapeutic management. An Med Interna. 2004;21(1):39-41.

5. Botella de Maglia J, Compte Torrero L, Rivas Sánchez A, Pérez Pastor JL. Triiodothyronine intoxication. A clinical and phamacokinetic study. An Med Interna. 2003;20(12):627-9.

6. Mandel SH, Magnusson AR, Burton BT, Swanson JR, LaFranchi SH. Massive levothyroxine ingestion. Conservative management. Clin Pediatr (Phila). 1989;28(8):374-6. http://dx.doi.org/10.1177/000992288902800808. PMid:2758719.

7. Mudoni A, Caccetta F, Caroppo M, Musio F, Accogli A, Zacheo MD, Burzo MD, Nuzzo V. Multi-organ failure after massive Levothyroxine ingestion: case report. G Ital Nefrol. 2015;32(1).

8. Beier C, Liebezeit B, Völkl TM, Zimdars K, Dörr HG. Attempted suicide with L-thyroxine in an adolescent girl. Klin Padiatr. 2006;218(1):34-7.

9. Matthews SJ. Acute thyroxine overdosage: two cases of parasuicide. Ulster Med J. 1993;62(2):170-3.

10. Hays HL, Jolliff HA, Casavant MJ. Thyrotoxicosis after a massive levothyroxine ingestion in a 3-year-old patient. Pediatr Emerg Care. 2013;29(11):1217-9. http:// dx.doi.org/10.1097/PEC.0b013e3182aa4714. PMid:24196094.

11. Kaiserman I, Avni M, Sack J. Kinetics of the pituitary-thyroid axis and the peripheral thyroid hormones in 2 children with thyroxine intoxication. Horm Res. 1995;44(5):229-37. http://dx.doi.org/10.1159/000184631. PMid:8582716. 


\section{*Correspondência}

Leandro Luongo Matos

Av. Dr. Enéas de Carvalho Aguiar, 255,

$8^{\circ}$ andar, sala 8174

CEP 05403-000, São Paulo (SP), Brasil

Tel.: +55 (11) 2661-6425; Fax: +55 (11)

2661-7506

E-mail: I.matos@fm.usp.br

\section{Authors information}

MRC - Acadêmica do Curso de Medicina da Faculdade de Medicina do ABC. AW - Coordenador geral do ceatox-sp. LLM - Professor Livre Docente, Disciplina de Cirurgia de Cabeça e Pescoço, Faculdade de Medicina da Universidade de São Paulo (LIM28); Cirurgião assistente do Instituto do Câncer do Estado de São Paulo.
12. Majlesi N, Greller HA, McGuigan MA, Caraccio T, Su MK, Chan GM. Thyroid storm after pediatric levothyroxine ingestion. Pediatrics. 2010;126(2):e470-3. http:// dx.doi.org/10.1542/peds.2009-2138. PMid:20643722.

13. Hartung B, Schott M, Daldrup T, Ritz-Timme S. Lethal thyroid storm after uncontrolled intake of liothyronine in order to lose weight. Int J Legal Med. 2010;124(6):637-40. http://dx.doi.org/10.1007/s00414-010-0423-y. PMid:20145940.

14. CEATOX-SP [Internet]. CEATOX-SP - O que fazemos. São Paulo: CEATOX-SP; 2006 [cited 2018 Dec 19]. Available from: http://www.ceatox.org.br/default. aspx?pagid=DKDHOQWN\&menuid=9114

15. Sistema Nacional de Informações Tóxico-Farmacológicas - SINITOX. FIOCRUZ/ MS, 1996 a 2006 [cited 2018 Dec 19] Available from: https://sinitox.icict.fiocruz.br/

16. Brasil. Lei $n^{\circ}$ 9.782, de 26 de janeiro de 1999. Define o Sistema Nacional de Vigilância Sanitária, cria a Agência Nacional de Vigilância Sanitária. Diário Oficial da República Federativa do Brasil; 1999 Jan 27.

17. São Paulo. Secretaria de Estado da Saúde de São Paulo. Centro de Vigilância Sanitária [Internet]. Instruções para o Preenchimento da Ficha Individual de Notificação de Eventos Toxicológicos. São Paulo: Centro de Vigilância Sanitária; [cited 2018 Dec 19]. Available from: http://www.cvs.saude.sp.gov.br/tox_inpreficha. asp

18. Minayo MCS. O desafio do conhecimento. 11a ed. São Paulo: Hucitec; 2008.

19. Brasil. Agência Nacional de Vigilância Sanitária. Bulário eletrônico: Bula Levotiroxina Sódica. Brasília: ANVISA; 2015. 